JPPUMA: Jurnal Ilmu Pemerintahan dan Sosial Politik UMA Uournal of Governance and Political Social

UMA), 8 (1) (2020): 28-36, DOI: https://doi.org/10.31289/ippuma.v8i1.2913

JPPUMA: Jurnal Ilmu Pemerintahan dan Sosial Politik UMA

(Journal of Governance and Political Social UMA)

Available online http://ojs.uma.ac.id/index.php/jppuma

\title{
Divided Government and Its Impact on the Performance of Legislation in the Indonesian Province of Aceh
}

\author{
Sultan Arief Azlansyah*, Retno Sunu Astuti \& Budi Puspo Priyadi \\ Masters in Administrative Sciences, Faculty of Social and Political Sciences, \\ Universitas Diponegoro, Indonesia
}

Recieved: November 12, 2019; Accepted: March 15, 2020; Published: June 2020

\begin{abstract}
The Indonesian Province of Aceh holds a special autonomy to have a local political party that is expected to promote the people's interests in Aceh. In this sense, the privileged autonomy should have to have a good governance performance. Nevertheless, it has not yet impacted significantly the performance of legislation. After the 2017 local election, two major local political parties dominate Aceh's provincial government, which discord with each other crucially that results in a divided government. This research aims to observe factors that take effect on the performance of legislation in the province of Aceh in the course of 2014 to 2018. This study employs qualitative methods. It reveals that in the legislation process, there is ineffective communication between the provincial government of Aceh and the local parliament (Dewan Perwakilan Rakyat Aceh/DPRA) to legislate a local regulation called qanun. This phenomenon is also triggered by the dispute over the parliament, which is split between two major local political parties. With ineffective communication between the government and the parliament, they did not work optimally to legislate many bills in every one-year term. Divided government leads to the vacuum or unproductivity of elements of the provincial government.
\end{abstract}

Keywords: Divided Government, Performance, Legislation

How to Cite: Azlansyah, S.A, Astuti, R.S \& Priyadi, B.P (2020). Divided Government and Its Impact on the Performance of Legislation in the Indonesian Province of Aceh. JPPUMA: Jurnal Ilmu Pemerintahan dan Sosial Politik UMA (Journal of Governance and Political Social UMA), 8 (1): 29-36.

*Corresponding author:

E-mail: sultanar060@gmail.com
ISSN 2549-1660 (Print)

ISSN 2550-1305 (Online) 


\section{INTRODUCTION}

Effectivity could be identified from the expected outcome and the real output that has been achieved (Mahmudi, 2010). One can measure the effectiveness of an organization by looking at its achievement as a whole and its expected target. Like governmental organizations, the performance can be seen from the accomplishment of its program or project in every term, such as the annual planned program or another period of the program.

Every state applies a different system of government, following the consensus or norms and values embraced and adopted by the state. Indonesia is the third-largest democratic state in the world after the United States of America and India. It is an archipelagic country with social and cultural diversity: various ethnic groups, religious beliefs, and local values in every region. Adopting the principle of "trias politica", Indonesia divides its governance system to three core elements, which are executive government, legislative body, and judicative.

Political decentralization has been applied to bring public service up to the local people. Experiencing a centralized government for decades, Indonesia turned to a decentralized government to solve the problems that concentrate on the central authority. The decentralized government is believed to be able to encourage economic growth and carry out a public policy that is oriented to the local interests (Bambang, 2017). Law No. 23 of 2014 defines Regional Governance as a governmental system consisted of governor in the executive body, and local parliament (Dewan Perwakilan Rakyat Daerah/ DPRD) as a legislative body, which is mandated to take responsibility on their functions following the regulation.

The Province of Aceh is one of the Indonesian regions that hold special autonomy to manage its governance. The autonomy has received from the 2005 Helsinki peace agreement as a negotiation between the central government of Indonesia and the Free Aceh Movement (Gerakan Aceh Merdeka/GAM) called Memorandum of Understanding (MoU). The agreement leads to several points that both sides have to obey. It becomes apparent that the Indonesian government gave autonomy to the Province of Aceh to apply its regional law based on Islamic sharia law and establish a local political party. The realization of the agreement has been formalized in legal norms in the Law No. 11 of 2006 on the Government of Aceh. This is a special autonomy or privileged right in founding local political party that the other Indonesian provinces do not have.

The involvement of local parties in the political arena in Aceh province contributes to the composition of seats in the local parliament of Aceh (DPRA), and further, their roles in the nomination of the executive leader (governor) in candidacy in the local election. A governor of Aceh in the period of 2007 - 2017 was a candidate nominated by a local political party. The composition of local parliament (DPRD) in the 2009 and 2014 general elections shows that the national parties form the majority of seats. While the local parties obtained less than the national parties. However, if we count the acquisition of every single party, the local party, Partai Aceh (the Party of Aceh) gained a majority of seats in the parliament (see figure 1).

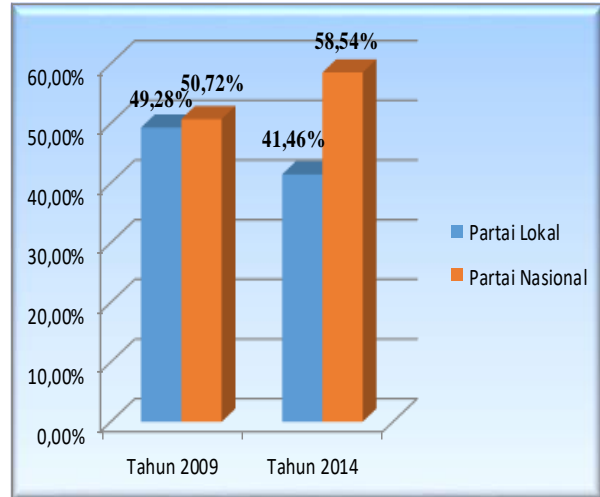

Figure 1 the Acquisition of Seats in Local

Parliament (DPRA) in the General Election of 2009 and 2014

Source: dpra.acehprov.go.id, 2019. 
Two local parties of Aceh dominate the provincial government of Aceh. Partai Aceh (the Party of Aceh) takes control of the legislative body (DPRD). While the candidate of the governor of Aceh was nominated by Partain Nangroe Aceh (the Party of Acehnese Country). Thus, each local party dominates each executive and legislative body. Eriyanto (2007) explains this phenomenon, that if the parliament is dominated by the opposition party (opposition to the legislative body), divided government is going to happen. The same phenomenon also takes place in several states in the world, such as in the United States of America. Schelker (2017) states that divided government will weaken one of the state institutions, primarily the executive body, which is called as 'lame duck'. The divided government is also possibly happening in Aceh, which will affect significantly the performance of the government in the legislation mechanism, which involves both legislative and executive institutions.

Following article 96 of Law No. 23 of 2014 on the regional governance, it is said that there are three functions of the legislative body, namely budgeting, monitoring, and legislation. The legislation process involves executive and legislative bodies to enact a regulation. In Aceh, this has been planned in the Regional Legislation Program (Program Legislasi Daerah/ Prolegda), in which both institutions have to agree on the enactment of a certain local regulation in a certain period. An assessment of the performance in the legislation of the Aceh's government can be viewed from its product, in how many regulations (qanun) have been approved in every single year. The enactment of qanun in the Regional Legislation Program (Prolegda) should achieve its plan to legislate all the bills in the period of the program. Nevertheless, the bills have not been enacted yet as a whole as planned (see table 1)

\begin{tabular}{|l|l|l|l|l|}
\hline No & Years & $\begin{array}{l}\text { Number of } \\
\text { Drafts } \\
\text { Qanun }\end{array}$ & $\begin{array}{l}\text { Enacted } \\
\text { Qanun }\end{array}$ & $(\%)$ \\
\hline 1 & 2015 & 15 & 9 & $60 \%$ \\
\hline 2 & 2016 & 13 & 13 & $100 \%$ \\
\hline 3 & 2017 & 26 & 17 & $\begin{array}{l}65,30 \\
\%\end{array}$ \\
\hline 4 & 2018 & 26 & 8 & $31 \%$ \\
\hline
\end{tabular}

Table 1 Draft bills of Qanun Aceh in 2015-2018.

Source: Documentation and Information

Management Agency (Pejabat Pengelola Informasi dan Dokumentasi) Aceh, 2019.

The Drafts included the legislation program (prolegda) every year is the task the government has to accomplish in a certain period. The enactment of Qanun (see table 1) exemplifies that the performance of Aceh's government in legislation has not yet reached an optimal achievement indicated by the number or qanun that have not been legislated yet by the collaborative work of the executive and legislative bodies.

The legalization of local budget (Anggaran Pendapatan dan Belanja Aceh/ APBA) is also part of the enactment of Aceh's qanun that has to be done every year. The legalization of APBA is necessary to manage all government's program and fiscal. Following the Minister of Home Affairs' Regulation No. 13 of 2016 on the regional budget, the legalization of the local budget has to be done at the latest is a month before the date of validity. This legalization aims to manage the use of local budget efficiently referring to the programs that have been approved.

The legalization that violates the regulation will affect the implementation of the budget. The delay in legalization will disturb the execution of projects that have been planned and scheduled before and affect to their punctuality and result (Serafiadita, 2015). The government plays larger roles in the whole process of legalization including the local budget. Furthermore, the approval of the draft of the local budget will be determined by the 
composition of a political faction in the government institutions involving in the decision making (Kartiko, 2012).

The enactment of the draft of the local budget in the period of 2015 to 2018 demonstrates that it has not met the condition regulated by the law. Even though this process has involved the executive and legislative institutions.

Table 2 The Approval of Local Budget of the Province of Aceh

\begin{tabular}{|l|l|l|}
\hline No & Budget term & Legalization date \\
\hline $\mathbf{1}$ & Budget of 2015 & 27 February 2015 \\
\hline $\mathbf{2}$ & Budget of 2016 & 22 February 2016 \\
\hline $\mathbf{3}$ & Budget of 2017 & 17 January 2017 \\
\hline $\mathbf{4}$ & Budget of 2018 & 21 March 2018 \\
\hline
\end{tabular}

Source: Seuramoe informasi Pemerintah Aceh, 2019.

Following the Regulation of the Minister of Home Affairs No. 13 of 2006 on the guidelines of management of the local budget, it is said that the local budget has to be valid starting from 1 January. Therefore, the legalization of the local budget of 2015 - 2018 has been done lately. This has violated the regulation.

This condition is in opposite to the distinction of the Province of Aceh as the only Indonesian region that has local political parties. This privileged right should have made the local government concentrates primarily on the local development goals with minimum intervention from the national authority. However, the political life in Aceh has been dominated by two rival political parties, in which one controls the executive and the other dominates legislative, which results in the divided government.

The legislation process cannot be separated from the politics in practices going on in a governance system. Though check and balance mechanism is expected to bolster a strong government with monitoring from the legislative body, the reality indicates that the political process goes for the sake of interests of political camps and put public interests under their priority. Whereas, with its privileged right and the local political parties, Aceh has been expected to have focused on the development at the local level. In reality, the problems show that the performance of the government in the legislation process is not optimal in the past four years, in which only some drafts have been legalized. Based on this situation, a question can be brought forward in this research, which is, what factors that obstruct the government of Aceh Province in its performance and the achievement in the legislation process?

Related to the research question, a hypothesis should be considered in this study, which is, that divided government affects the performance of Aceh's government in the legislation process. This study aims to analyze the legislative process that is affected by the political situation under divided government.

Performance is a multidimensional construct formed and affected by many factors. Simply put, Campbell (Mahmudi, 2015) states that performance is affected by several factors, namely knowledge, skills, and motivation.

The performance of an organization reflects the performances of its employees (individuals). If any employee shows his or her performance well, the performance of the organization will be good. Likewise, if the performance of individuals is bad, so is the performance of the organization. According to Dwiyanto, the performance of the Indonesian bureaucracy has been influenced by several factors, namely social environment, cultural values, Weberian bureaucratic structure, pathology of organization, in which every element is connected (Dwiyanto, 2015).

The performance of an organization is influenced by two factors, namely internal and external-coming from within and outside the organization. According to Mahmudi, several factors influence the performance of an organization, namely, social environment, leadership, organization culture, opted strategy, 
technology, organization structure and organization process (Mahmudi, 2015). The other theory says that factors affecting the performance of an organization can be classified into three indicators, namely external and internal environments and the employee's environment of an organization (Wirawan, 2009). Based on the above theory, the author can summarize several indicators that influence the performance of an organization by adjusting to the focus and topic of this research. Taking the indicators to this study, factors that form the performance of legislation in the province of Aceh are political environment and public participation.

'Divided Government' is a political phenomenon in which there is a split between the executive and legislative institutions. This shows also the split of interests and political direction, which are not inline, even contradict each other in the context of policymaking. In the practice of institutional structure, the legalization of a policy does not only depend on the executive roles but also legislative composition (Laver, 1996 in Kartiko, 2012). Further, the 'divided government' is a situation when two primary democratic institutions in the political system, executive and legislative, each has been dominated by two different political parties. Promoting their political interests, each political party in the divided government is not always harmonious in the policymaking, which in this case is in the context of legislation.

According to Eriyanto (2007), the divided government happens when the local leader (regent or governor) does not come from or is not nominated by the political party that forms majority seats in the Parliament (DPRD). On the contrary, the unified government happens when the local leader and its deputy comes from the same political party that forms the majority of parliament members. The divided government illustrates many ruptures, tensions, and conflicts driven by political elites and also bureaucratic institutions. Prolongation of the ruptures, tensions will sharpen the conflicts resulting in the performance of government institutions.

The cycle of the local election leads to the change of the ruling party championing the election. The difference of the ruling party in legislative and executive bodies has led to the situation of 'divided government', which further affects the legislation of the local regulation, and specifically in the legalization of local budge, APBD (Kartiko, 2012).

\section{RESEARCH METHOD}

This study applies the qualitative methods to get deeper information about the phenomenon of divided government, namely by a series of interviews with several informants, who are the members of the local parliaments (DPRA), observation, and looking at several documents. This research also compares the sources with the other sources to get understood of the whole situation (Moleong, 2005).

\section{RESULT AND DISCUSSION Legislation Performance}

Law No. 18 of 2001 gives a special autonomy for Aceh as the province of Nanggroes Aceh Darussalam. In the law, the government of the Aceh Province consists of the governor and other apparatus within the executive body, the legislative body or Dewan Perwakilan Rakyat Aceh (DPRA) that function collaboratively in drafting and enacting local regulation (qanun). The qanun, normatively, regulates the people's life and government's policy to realize the prosperity and security in the province of Aceh.

The Regional government is responsible for a product of legislation enacted in the region. The making of the 
local regulation is a collaborative work by the governor or regent and local parliament (DPRD). Law No. 23 of 2014 on the Regional Government, article 65 mentions that the regional leader holds a right to file $a$ bill to the regional parliament. The regional leader has been given authority to file a bill as efforts to meet his or her political promises in the political campaign in the election and to implement his or her tasks delegated by the law.

The making or local regulation is managed collaboratively by the government and local parliament for an agreement in the plenary meeting held in the parliament. A local regulation, qanun, could be initiated and filed either by the governor or the parliament, which is normatively based on the Aceh people's aspiration. The scheme of regulationmaking is not merely a talk between the policymakers. Rather, it has to involve the other stakeholders, such as civil society, academics, and political parties, which have necessary contributions to asses the content of the draft of the bill.

\section{Factors Affecting the Legislation Process}

Public Participation. Public participation is needed in the process of policymaking because the policy impacts directly to the society. It is, therefore, by participating in the process the public gives inputs to the government so that the enacted policy will not result in the new problems in the life of society. Qanun No 1 of 2015 on the legislation procedures necessitates every member of the parliament to make recess at least three times and maximum six times in a year. The recess is conducted by every senator to collect and accommodate aspirations from his or her constituents. Besides recess, in the process of legislation, the government also regulates the mechanism to involve civil society to convey inputs or recommendations to the draft of bills.
Qanun No 5 of 2011 on the procedures of qanun making mentions that in the scheme of the qanun making the process has to involve society in the general meeting of public hearings (Rapat Umum Dengar Pendapat Umum/RUDP).

This study reveals that the scheme of public participation in the RUDP is an obligatory stage that has to be met. While the public has to be involved in those who have a certain capacity and can deliver their opinions on the legislation product. The social groups involved in this process are coming from various backgrounds, such as ordinary people, academics, youth organizations, NGOs and other groups that are related to the draft of bills. RUDP functions to look at the public responses in assessing and giving opinions to the draft of bills initiated by the government of Aceh. RUDP can function strongly to change the content of the bills. As it is known that the implementation of local regulation is not only the domain of the government and the elites but also connected intimately with the people generally and become a reference of Aceh people in resolving their disputes.

The involvement of Aceh people can be managed by organizing public seminars in many places such as university campus or other places following the district or constituency of members of Parliament. As conveyed by a member of a student organization HIMMAH that "in involving society NGOs is always there, but the product of legislation does not necessarily fit the public expectation. It was merely a formality". RUDP is a step that is obligatorily conducted by the government of Aceh Province, but mostly to meet the formal procedures of government obligation in the legislation process.

The making of local regulation has to consider the public interests as Aceh people as a whole so that its implementation will not affect negatively the people as a whole. RUDP has to become a necessary activity to observe public 
responses so their aspirations can be considered well by the Aceh government in the legalization of the local regulation.

Political Environment. The legislation program is a series of processes that cannot be separated from political interests. The decision made by the government contains political ends as well. Referring to the data of legalization of qanun in the Regional Legislation Program (Program Legislasi Daerah/Prolegda) in 2015 - 2018, there are on average 64,07 percent of the bills legalized, which indicates the Aceh government has not yet effectively legalized all the draft of bills.

The political context in Aceh formed by two dominant local parties of Aceh, which each dominate the executive and legislative institutions and are opposite each other since the local election in 2017. This impacts the accomplishment of the government's programs that have been the obligation of the Aceh government. One of the effects of the problem can be looked at the phase of decision making collaboratively in the legalization of the local budget in 2018. The local budget had been suspended and fell into deadlock so the governor of Aceh took an action to legalize it in a form of Governor's Regulation. Even though, the local budget has to be legalized in a Regional Regulation or Perda, which in Aceh called Qanun. This problem is because of the bad communication between the local parliament (DPRA) and the executive. A member of DPRA in the Commission I states that it is because of,

"the bad communication between DPRD and the Provincial Government at every moment of the final decision making. This can be seen in the performance of the government as a whole"

"kurang baiknya komunikasi politik antara DPRA dengan Pemerintah Aceh pada setiap pengambilan keputusan akhir. Hal tersebut terlihat dalam bentuk kinerja Pemerintahan Aceh secara keseluruhan"

On the other hand, head of subdivision of the Regional Secretariat of Aceh explains that,

"The legalization of Qanun Aceh has been stagnated at the stage of discussion at the level of Commission in the Local Parliament, and this delay will impact the following phase"

"penyelesaian Qanun Aceh tersendat pada tahap pembahasan ditingkat komisi-komisi di DPRA, keterlambatan tersebut akan berdampak pada fase lainnya".

Besides the communication problem, the other problem is also triggered by the team established by the Aceh government in dealing with DPRA, which promotes mostly their interests without considering the inputs given by other Parliament members. While this legislative institution has the obligation to promote public participation to the government and to make an agreement as both are public institutions. The different interpretations manifest in the performance of the Aceh government as a whole, lack of coordination between legislative and executive bodies, which can grow public distrust to the government.

On the other hand, the proposal of a bill mostly initiated by the government. However, it is stuck in the debate with the parliament in the discussion about the bill. This situation has been stimulated by most parliament members imposing their interests to take advantage of the program initiated and implemented by the government.

The Coalition of parties dominating the Local Parliament stands to oppose the government. This stance is necessary to support and evaluate critically the proposal initiated by the government to the parliament. Nevertheless, in reality, the parliament forms a group of opposition to the government, which is called the 
Dignified Acehnese Coalition Koalisi Aceh Bermartabat (KAB). The problem is that the government is not supported by the parliament so that it makes a problem between them.

The above explanation demonstrates that the problems of the Aceh government are not based on the conflict among the parliament members. Every member of the parliament focuses on promoting and advocating public interests to be accommodated collaboratively.

The conflict between the government and the parliament is a problem that should have to be avoided to maximize the implementation of their tasks. The government, normatively, has to be a good partner in the process of check and balance so that the ideal condition to carry out their task could be achieved.

This will impact the performance of the government every year. In research, Schelker (2017) reveals that the phenomenon of divided government in the governance system will weaken the power of one of the institutions, which is the executive body, or what is called lame duck. This weakness is because the government cannot make a decision freely due to the split between the executive and legislative each supported by different political parties.

The prolonged conflict will not only impact the performance of the Aceh government. It will also affect public interests in the governance system in adjudicating the problems in society. This situation will be a deprivation fort he Province of Aceh in developing the region with the privileged right given by the central government, which cannot be used as optimal as possible.

\section{CONCLUSION}

This research focuses on the factors that work in the legislation process in the Province of Aceh. It concludes that the process of drafting the local regulation or qanun in the Province of Aceh can be initiated either by the executive or legislative bodies to be legalized collaboratively. Disharmony between the government and the parliament creates a miscommunication so there is a dissent understanding in the legalization process that impacts the performance of the government. Looking at the component of the government of Aceh, the phenomenon of divided government is happening and can be seen at the unproductivity of one of the elements of the Aceh Government in implementing its tasks.

\section{ACKNOWLEDGMENT}

I thank the head of the Master Program of Public Administration and the other academic staff. I also thank my thesis supervisor and his family who have given moral support

\section{BIBLIOGRAPHY}

Bungin, B, (2007). Penelitian Kualitatif [Qualitative Research]. Jakarta: PT. Rineka Cipta.

Devota. S. (2015). Analisis Pengaruh Keterlambatan Penyusunan Dan Penetapan Apbd Terhadap Penyerapan Anggaran Skpd Di Kabupaten Boven Digoel Tahun Anggaran 2014 [Analysis of the effect of the delay in drafting and legislating local budget to the use of budget by government agencies in the Regency of Boven Digoel in 2014]. Jurnal Kajian Ekonomi dan Studi Pembangunan. 2(1): 41-60.

Dwiyanto, Agus. (2015). Manajemen Pelayanan Publik [Public Policy Management]. Yogyakarta: Gajah Mada University Press.

Eriyanto. (2012). Pilkada dan Pemerintahan yang Terbelah (divided government) Edisi 07 November 2007 [Local Election and the divided government]. Lingkaran survai Indonesia. 12(2): 83-106.

Kartiko, S.W. (2011). Pengaruh Ketidakmayoritasan Partai Politik Kepala Daerah Dalam DPRD (Divided Government) Terhadap Keterlambatan Penetapan APBD (Budget Delay) Berdasarkan Perspektif Ekonomi politik, Tesis. Jakarta: Universitas Indonesia.

Moleong, L.J. (2005). Metodologi Penelitian Kualitatif [Qualitative Research Methods]. Bandung: Remaja Rosdakarya.

Mahmudi. (2015). Manajemen Kinerja Sektor Publik [Performance Management of Public Sector]. Yogyakarta: Sekolah Tinggi Ilmu Manajemen YKPN. 
Sultan Arief Azlansyah, Retno Sunu Astuti \& Budi Puspo Priyadi, Divided Government and Its

Peraturan Menteri Dalam Negeri Nomor 13 tahun 2016 tentang Keuangan Daerah [Minister of Home Affairs' Regulation No. 13 of 2016 on the Regional Finance].

Qanun Nomor 5 tahun 2011 tentang Tata Cara Pembentukan Qanun [Local Regulation No. 5 of 2011 on the procedures of qanun legislation].

Qanun Nomor 1 Tahun 2016 tentang Tata Tertib DPRA [Local Regulation No 1 of 2016 on the code of conduct of the Aceh's local parliament].

Mark, S. (2017). Lame Ducks And Divided Government: How Voters Control The Unaccountable. Journal of Comparative Economics. 21(0): 1-14.

Sugiyono. (2010). Metode Penelitian Bisnis (Pendekatan Kuantitatif, Kualitatif R\&D) [Business Research Methods, Quantitative, Qualitative and Research and Development Approaches]. Bandung: Alfabeta.

Undang-undang Nomor 18 tahun 2001 tentang Otonomi Khusus Bagi Aceh sebagai Provinsi Nanggroe Aceh Darussalam [Law No. 18 of
2001 on Special Autonomy in Aceh as the Province of Nanggroe Aceh Darussalam].

Undang-undang Nomor 23 Tahun 2014 tentang Pemerintahan Daerah [Law No. 23 of 2014 on Regional Government].

Pemerintahan Aceh. 2019. Pengesahan Anggaran Pendapatan dan Belanja Aceh [Legalization of Local Budget of Aceh Province]. Diunduh di https://seuramoe.acehprov.go.id/ 8 Januari 2019.

Pejabat Pengelola Informasi dan Dokumentasi Aceh, 2019. Rancangan Qanun dan Qanun Aceh tahun 2015-2018 [Draft of Qanun and Aceh's Qanun in the period of 2015-2018]. Diunduh di https://ppid.acehprov.go.id./ 5 Januari 2019.

Purwoko, B, dkk. (2017). Desentralisasi Radikal [Radical Decentralization]. Bantul: Ifada Publishing.

Wirawan. (2009). Evaluasi Kinerja Sumber daya Manusia Teori Aplikasi dan Penelitian [Assesment oft he Performance of Human Resources, Theory and Practices]. Jakarta: Salemba Empat. 